University of Wollongong

Research Online

Faculty of Business - Papers (Archive)

Faculty of Business and Law

$1-1-2016$

People's Republic of China (PRC): Thailand economic relationship after signing of free trade agreement in 2005

Ying Liu

S P Jain School of Global Management, yliu@uow.edu.au

Kankesu Jayanthakumaran

University of Wollongong, kankesu@uow.edu.au

Follow this and additional works at: https://ro.uow.edu.au/buspapers

Part of the Business Commons

Research Online is the open access institutional repository for the University of Wollongong. For further information contact the UOW Library: research-pubs@uow.edu.au 


\title{
People's Republic of China (PRC): Thailand economic relationship after signing of free trade agreement in 2005
}

\begin{abstract}
People's Republic of China (PRC) is the third biggest nation globally situated in East Asia with the land area of 9.6 million $\mathrm{km} 2$, population of 1.36 billion people and population density of $139 \mathrm{~km}-2$. PRC's capital is Beijing and comprises of 22 provinces, five autonomous regions, four municipalities and two special administrative regions. Special administrative regions are Hong Kong and Macao. Thailand is the world's 51st largest country situated in Southeast Asia with the land area of 513,000 km2 and population of 67.1 million people. The population density of Thailand is around $131 \mathrm{~km}-2$. Thailand shares borders with four neighbmtrs: Myarunar in the north, Laos People's Democratic Republic (LPDR) and Cambodia in the east, and Malaysian Peninsula and Malaysia in the south. Myanmar and LPDR are the borders of PRC.
\end{abstract}

\section{Keywords}

signing, people, after, relationship, economic, thailand, prc, china, 2005, agreement, trade, free, republic

Disciplines

Business

\section{Publication Details}

Liu, Y. \& Jayanthakumaran, K. (2016). People's Republic of China (PRC): Thailand economic relationship after signing of free trade agreement in 2005. In K. Young-Chan (Eds.), Chinese Global Production Networks in ASEAN (pp. 77-95). united States: Springer. 


\title{
People's Republic of China (PRC) - Thailand economic relationship after signing of free trade agreement in 2005
}

\author{
Ying Liu \\ S P Jain School of Global Management \\ 5 Figtree Drive, Sydney Olympic Park, NSW 2127, Australia \\ and \\ Kankesu Jayanthakumaran \\ School of Accounting, Economics and Finance \\ Faculty of Business, University of Wollongong, NSW 2511, Australia
}

\begin{abstract}
The bilateral trade relations between People's Republic of China (PRC) and Thailand have considerably increased following the signing of the PRC - ASEAN Free Trade Agreement (CAFTA) on 'Trade in Goods' in July 2005, the 'Trade in Services' in 2007 and 'Investment' in 2009. The aim of this chapter is to explore the micro level comparative advantages between China and Thailand from the perspective of CAFTA. Revealed comparative advantages (RCA) indices have been estimated for exports at HS-2 digit level. The stability of the measure has also been tested. PRC has RCA for 39 of the 60 industries at two-digital SITC in 2010-13. While 4 industries drop their advantage in Thailand market 6 new industries gained advantage in 2010-13. The structure of PRC's RCA in Thai market has not changed extraordinarily during the study period concerned.
\end{abstract}

Corresponding Author

Ying Liu

S P Jain School of Global Management

5 Figtree Drive, Sydney Olympic Park, NSW 2127, Australia

Tel: 61289706837

Email: ying.liu@spjain.org 


\section{Background}

People's Republic of China (PRC) is the $3^{\text {rd }}$ biggest nation globally situated in East Asia with the land area of 9.6 million $\mathrm{km}$ square, population of 1.36 billion people and population density of 139 per square $\mathrm{km}$. PRC's capital is Beijing and comprises of 22 provinces, 5 autonomous regions, 4 municipalities and 2 special administrative regions. Special administrative regions are Hong Kong and Macao. Thailand is the world's $51^{\text {st }}$ - largest country situated in South East Asia with the land area of 513,000 km square and population of 67.1 million people. The population density of Thailand is around 131 per square $\mathrm{km}$. Thailand shares borders with four neighbours: Myanmar in the north, Laos People's Democratic Republic (LPDR) and Cambodia in the east, and Malaysian Peninsula and Malaysia in the south. Myanmar and LPDR are the borders of PRC.

PRC - Thailand bilateral relations in the form of commercial and cultural exchanges were historical one during the Ming and Qing dynasties and lasted consistently with few interruptions over time. ${ }^{1}$ After the Second World War, both countries strengthened their relationship by signing the Siam-PRC treaty. However, mutual suspicion prevailed for two reasons of one PRC involvement with Cambodia's conflicts and the other PRC's support to the communist factions within the Thai political circle. In 1978, PRC offered support to Thailand in resolving Cambodia's internal conflict and both countries signed the ThailandChina Joint Trade Committee (JTC) agreement. JTC is to promote bi-lateral trade volume goals and trade expansion. In 1985, both countries signed a contract on 'Promotion and Protection of Mutual Investment'. Since then trade and investment became the dominant theme in bilateral relations. Thailand supports the 'One PRC' Policy and maintains unofficial relations with Taiwan. ${ }^{2}$

PRC had the relatively closed economy prior to 1978 initiated economic reforms since then and intensified them by joining World Trade Organisation (WTO) in 2002. The 1990s and 2000s perceived a speedy growth performance in the Chinese economy, reflected in reduced

\footnotetext{
1 For detail see Thailand China Economic Information - The Long-stream friendship, http://www.thailand-china.com/getdoc/3aab868f-0b9e-4b1d-bcf1-e93bb80ec7b8/The-Longstream.aspx?lang=en-GB, accessed on 16 September 2014.

${ }^{2}$ In 1998, the China-Thailand subcommittee on co-operations in Trade, Investment and Tourism was created to strengthen the cooperation. This committee was terminated in 2001 after the change of governments from Democrats to the Thai Rak Thai party.
} 
trade and investment barriers, improved trade, the quick technology transmission, and greatly mobile factors of production such as capital and labour. Special economic zones (SPZs) were formed along the coastal line to invite Foreign Direct Investment (FDI) and lift exports and imports of advance technology based products. State-owned firms were permitted to function and adopt on free market-based principles and private firms were promoted and legalised. Such arrangements facilitated Thai investments in China especially in the areas of papermaking, electricity, agro-industries, textiles and garments, auto parts, food beverage, hotels, banking and building materials.

The well-known Charoen Pokphand Group (CP Group) firm originated in Thailand owned by Thai-Chinese, initiated the operation in PRC in the early 1980s and currently involved with a range of products that include automotive, petrochemicals, retail distribution, agribusiness and agro-industries. In the early 1990s, more Thai companies such as the Cement Thai group, Saha-Union Group and M-Thai Group started operation in PRC. Other Thai companies operating in China are Thai Farmer Bank (Kasikorn Bank), Kasetrungrueng Co. Ltd., Katingdaeng (Red Gore) Group, Krungthai Bank. Bangkok Bank Co. Ltd., and Mitphol Group.

Thailand was isolationist and dependent on state-owned enterprises and agricultural exports such as rice, sugar cane and cassava prior to 1970s. In the early 1980s, Thai economy slumped mainly due to the burden of high oil prices, debt crisis and decline in agricultural prices. This was addressed not only by using fiscal and monetary policies but also promoting exports by providing incentives such as exceptions and declines of tariffs and business taxes on imported intermediate inputs to all export projects. Free market policies steered to the intense development of an immense export-oriented, big-scale manufacturing sector, which in turn stimulated the economy linking the other extraordinary performance economies in Asia. Thailand's population comprised of around 14 percent of ethnic Chinese. Thai Chinese are highly influential in Thai economy and control major part of the firms registered on the stock market and the major part of market capitalisation. Thai Chinese entrepreneurs control in majority of the sectors including agriculture, banking and finance, real estate and wholesale trade. Such cultural links facilitated Chinese investments in Thailand especially in the areas of agribusiness, textiles, electronics, rubber, chemicals, hotels, restaurants and real estate. 
The Agreement on Promotion and Protection of Mutual Investment was signed in 1985 to promote trade and investment. This agreement facilitated PRC's direct investment in Thailand. Investments prior to 1985 were mainly in the form of trading but not production. The time period fall into initial stage of opening the PRC economy to the rest of the world. PRC's political rationale towards inward FDI could be characterized as selective acceptance. PRC invited only selective investments and allowed big trading companies to go overseas. The World best Group (textiles and garments), TCL Corporation (electronics) and Huawei Technology Corporation (wireless phone and networking equipment) are big investors in Thailand originated from China right after signing the agreement.

Major breakthrough occurred with the signing of the PRC - ASEAN Free Trade Agreement (CAFTA) in 2002 and subsequent agreements of goods, services and investment within the decade. The bilateral trade and investment between PRC and Thailand have remarkably increased since signing of CAFTA. This shows that there are diversities in comparative advantage between two countries economically in the use of natural resources and the stage of economic development. The changing pattern of comparative advantages between two countries would shape the long-term sustainable economic relationship.

To capture the comparative advantage, the estimates of Revealed Comparative Advantage (RCA) indices are widely applied to find changing pattern of bilateral comparative advantage (Utkulu and Seymen, 2004). Such estimate is lacking in PRC - Thailand exports and therefore, this chapter intends to fill the research gap to show the estimates of PRC's export competitiveness to Thailand. The chapter is structured as follows: the following section describes the bilateral trade agreements and performance between two economies. Section 3 explores the RCA indices. Empirical results of RCA indices and comparisons are presented in section 4 . The concluding section draws the findings.

\section{Trade and investment dependence between the two economies}

Economic integration is viewed as an opportunity for more trade and investment. It contributes more jobs, greater demand for consumption and more economic growth. A successful economic integration can occur only if there is evidence of greater bilateral trade between the partner countries. The last decade witnessed massive expansion of PRCThailand bilateral trade and investment and this reflects the existing complementarity of both 
economies. One can see that PRC-Thailand economic relationship is successful mainly due to Thailand's greater participation in the Association of Southeast Asian Nations Free Trade Area (ASEANFTA). In 1997, ASEANFTA initiated the process of accommodating ASEAN plus China, Korea and Japan (ASEAN+3). This all process facilitated CAFTA formation.

Thailand is one of the prominent members of the ASEANFTA. Studies indicate that there was a significant macroeconomic compatibility among the founder members of ASEAN (Ong and Habibullah, 2012). ${ }^{3}$ ASEAN countries attempted to integrate PRC in November 2002. A rapid expansion of bilateral economic relations occurred right after signing China (PRC)-ASEAN Free Trade Area (CAFTA) in 2002 with the intension of forming a free trade area by 2010 . The consistent steps have been taken by signing three agreements to integrate more; the Agreement on Trade in Goods in 2004, the Agreement on Trade in Services in 2007 and ASEAN-China Investment Agreement in 2009. Ong and Habibullah (2012) find that ASEAN - 5 and PRC integration have been more coordinated than just an ASEAN-5 macroeconomic compatibility using a cointegration analysis. Authors suggested more ASEAN - PRC coordination plan for further success.

Under the umbrella of CAFTA, in 2003, the PRC-Thailand FTA attempted 'early harvest' agreement on farm trade enforcing a deal to bring zero tariffs for 188 types fruits and vegetables. Both countries opened up their farm products prior to CAFTA comes into force in 2010. Although there are few accusations (for example, small farmers are not benefiting and cheaper PRC's fruits in the Thai market) of 'early harvest' agreement, countries formed a joint working group to study the problems and obstacles. The bilateral trade relationship is positive and PRC became Thailand's second largest trade partner after Japan in 2011.

Shen (2013) argues that there are three positive factors in boosting the expansion of PRC Thailand bilateral economic relations: Thailand is truly committed in the building of PRC and ASEAN FTA; PRC's 'Good Neighbouring' diplomacy had wider implications for positive implications of the agreement; the existing close contacts of different level of leadership since the signed up of agreement. Laurenceson (2003) pointed out goods and services market reforms in PRC - ASEAN 5 countries can be complementary to greater levels of external

\footnotetext{
${ }^{3}$ In 1967, founder members - Malaysia, Indonesia, Thailand, the Philippines and Singapore - formed the ASEAN - 5. By incorporating Brunei the ASEAN - 6 emerged in 1984. The ASEAN-10 countries include new members; Myanmar in 1997, Cambodia in 1999, Laos in 1997, and Vietnam in 1995.
} 
financial liberalisation, such as regulatory reforms of financial institutions. Regulatory reforms should cater the risk management practices of financial institutions in order to safeguard from financial crisis. Such move has already been initiated by liberalising trade in services but long way to go to finish the agenda.

An important question is that how the CAFTA and PRC - Thailand FTA impacted the PRC and Thailand as mutual trading and investing partners. Trade between the PRC and Thailand has grown in volume continuously and both countries remains as major export markets for each other since signing CAFTA. Figure 1 shows importance of PRC market for Thailand's exports and Thailand market for PRC's exports. Thai exports to the PRC increased from 5.2 per cent in 2002 to 11.9 per cent in 2013 while PRC's exports to Thailand increased from 15 per cent to 17 per cent during this period. Figure 1 also show that a remarkable increase of export shares by both countries as soon as 'Investment' agreement is signed in 2009 under CAFTA.

Figure 1: Relative importance of China and Thailand as exports and imports markets (in \%)

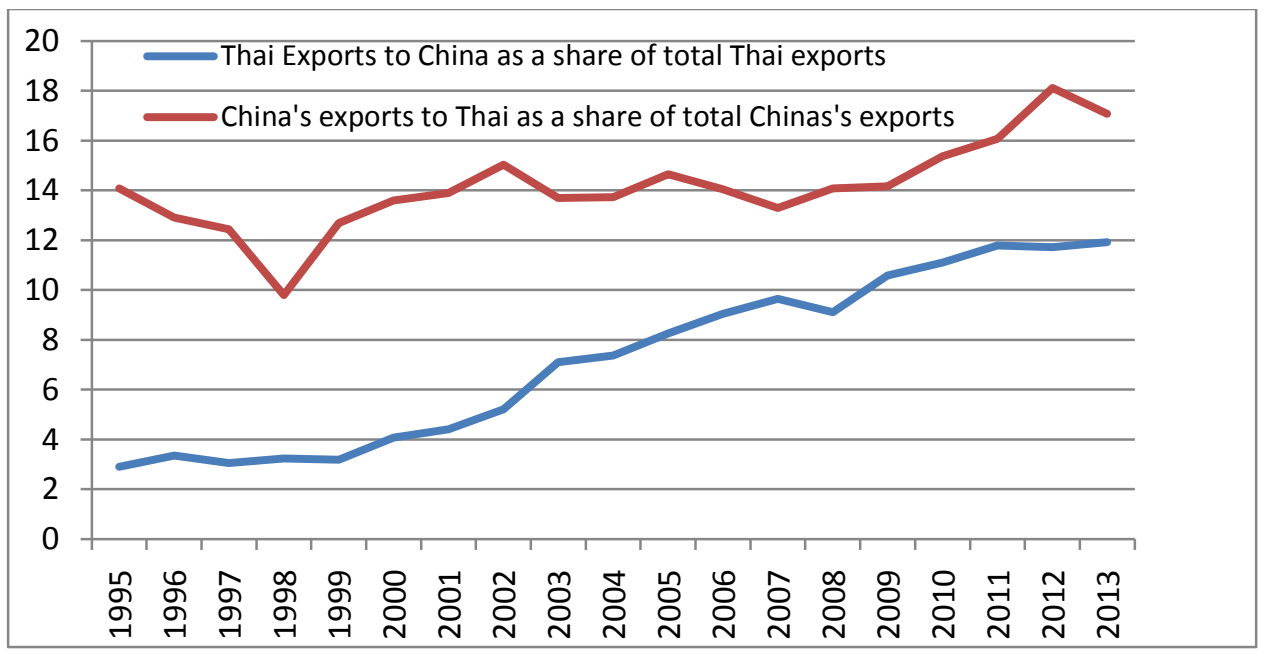

Source: Bank of Thailand (2014)

Figure 2 shows the importance of PRC as a source of Thailand's imports and Thailand as a source of PRC's imports. Thai imports to the China increased from 7.6 per cent to 15 per cent from 2002 to 2013 while PRC's imports to Thailand increased from 12 per cent to 14 per cent during this period. Both countries benefited by increasing their importance for each other following signing of CAFTA. Changes in Thai trade structure over the period reflect the 
impact of PRC's growing economic footprint. Figure 2 indicates a remarkable increase in import share by Thailand as soon as 'Investment' agreement is signed in 2009 under CAFTA.

Figure 2: Relative importance of China and Thailand as exports and imports markets (in \%)

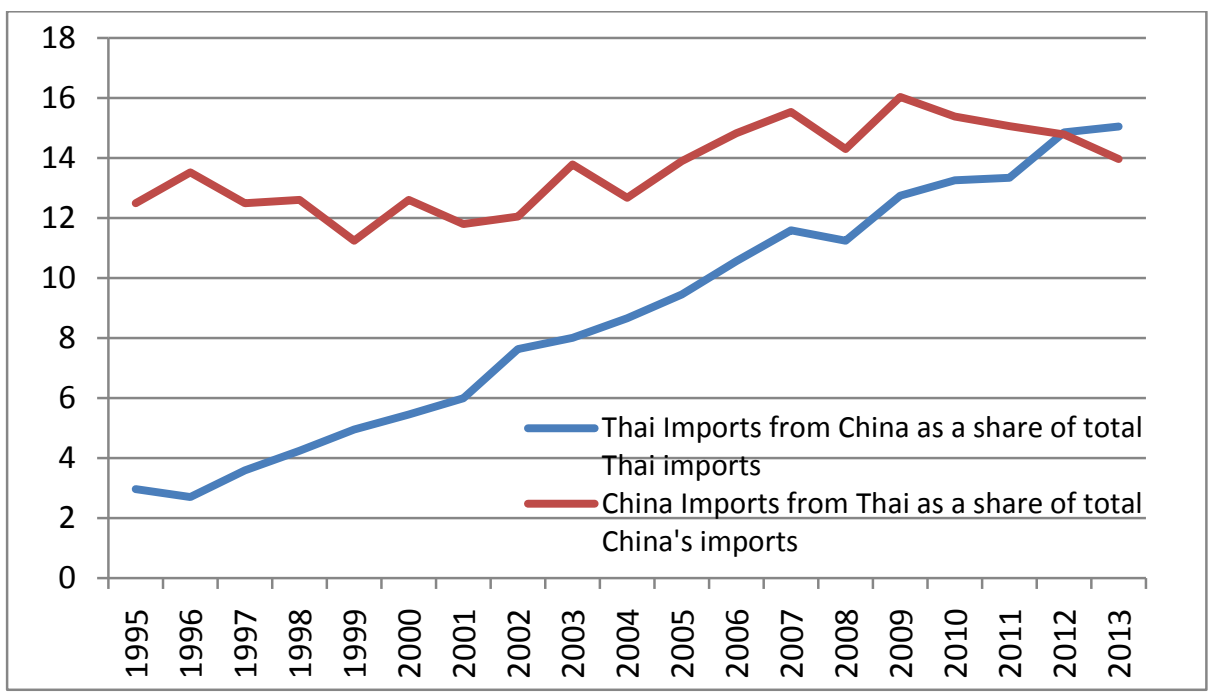

Source: Bank of Thailand (2014)

In recent years, mutual investments between PRC and Thailand have increased considerably. Official net FDI flows from China to Thailand peaked at US\$707 million in 2010 and have remained high since then (Figure 3). FDI net flows as a percentage of overall FDI peaked 7.7 per cent in both 2010 and 2011 and have remained at a modest 5 per cent. ASEAN FDI flows to Thailand as a percentage of overall FDI became negative in 2011 and 2012. This shows that FDI from China to the Thailand remains attractive after signing 'PRC-Thailand Investment Agreement' in 2009. 
Figure 3: FDI net flows to Thailand: From ASEAN and China (as a \% of overall FDI)

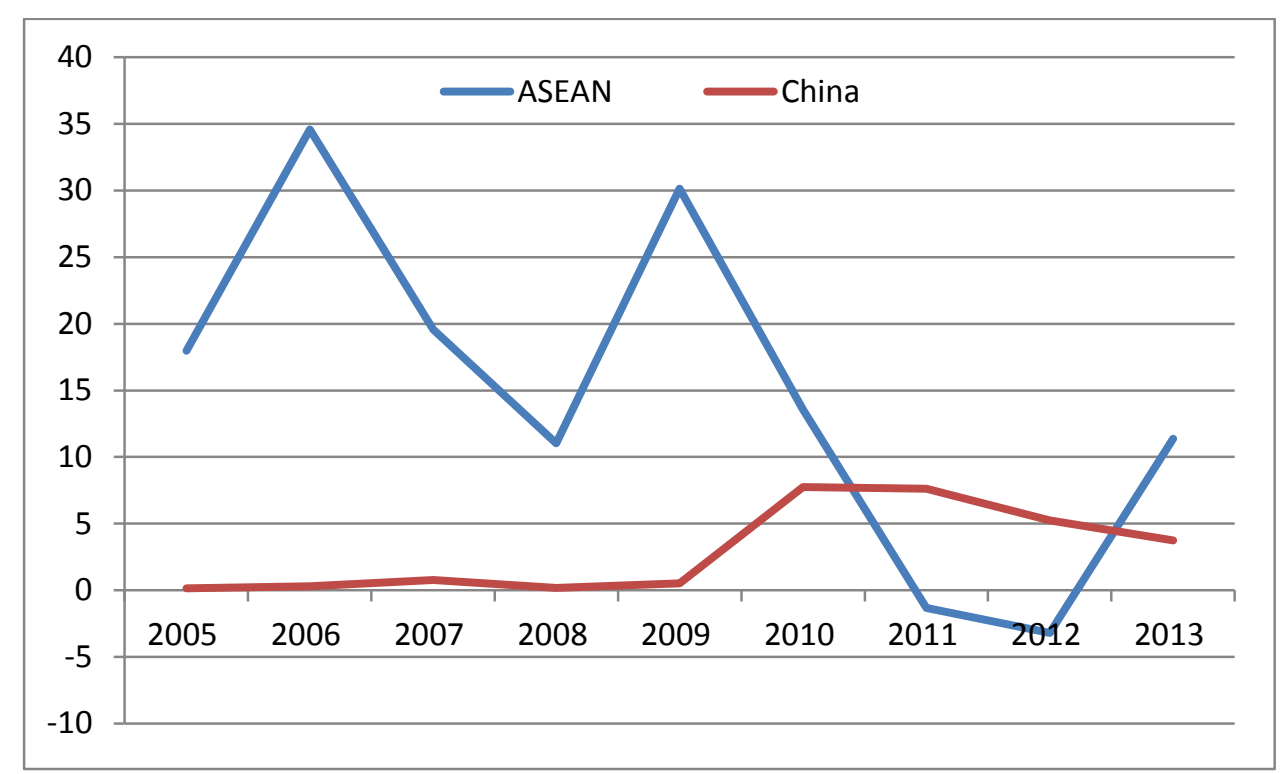

Source: Bank of Thailand (2014)

PRC's exchange rate policy contains substantial intervention in the currency market to avert Yuan's appreciation against the five major trading partners' currency where Thailand involves with more managed floating regime. PRC's nominal currency rate relative to the US\$ was smooth until 2005 (Figure 4). In 2005, Chinese yuan was fixed with the basket of currencies (the euro, the US dollar, the Japanese yen and the Korean won) and allowed 2 per cent appreciation. The exchange rate band has remained 0.5 percent above and below since mid-2007, when it was increased from 0.3 percent. Thailand's nominal exchange rate relative to the Chinese yuan was also flat while Thai baht against US Dollar depreciates and appreciates after Asian crisis. PRC's interventionist currency policy can encourage PRC's exports to Thailand but not imports. Thus, the Thai current account deficit hit US\$10,488 million in 2013 which is -16 per cent of overall bilateral trade between Thailand and PRC. 
Figure 4: Exchange rates

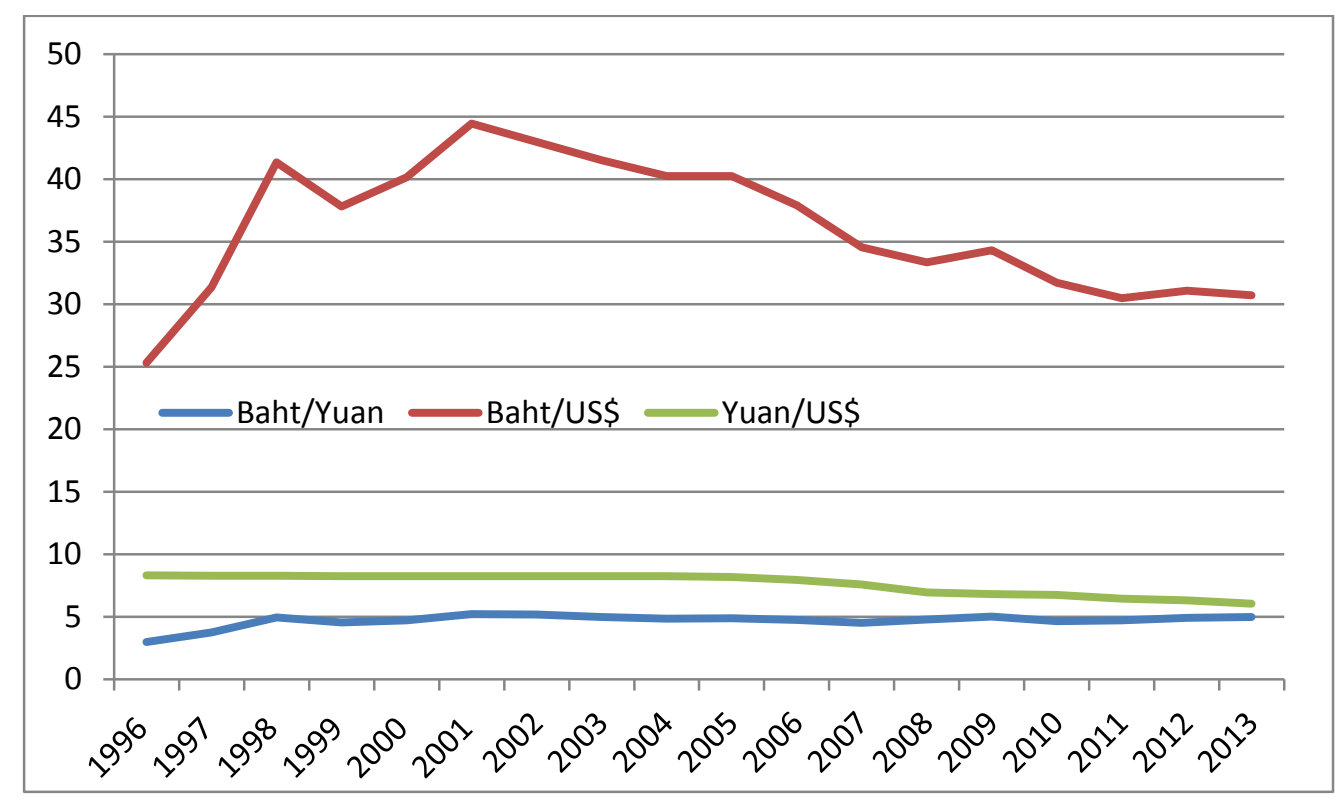

Source: Bank of Thailand (2014) and IMF (2014)

The evidence shows that PRC's trade and investment relations with Thailand have remained robust after signing the CAFTA and a remarkable increase in trade and investment share since 2009. In recent years, more emphasis has been placed on trade in services and with fully opening there will be more service trade relationships.

\section{Method of estimating RCA}

A nation which may generate or produce at lower relative cost than other nations can distribute more of its limited resources to the manufacture of that specific good. ${ }^{4}$ In the wake of a progressively competitive international environment with accompanied liberalisation of trade and investment, it is appropriate to observe the changing pattern of comparative advantage. Comparative advantages vary overtime. In this sense, it is dynamic. The estimates of changing pattern of comparative advantages are useful information for policy makers.

Balassa's (1965) measure of Revealed Comparative Advantage (RCA) is a widely known measure to capture the effect of factor supplies and technology on comparative advantage.

\footnotetext{
${ }^{4}$ Heckscher-Ohlin (H-O) model says that comparative advantage of a country lies on its relative factor scarcity. Balassa (1965) advocates that comparative advantage is revealed by observed trade patterns and reflects through pre-trade relative prices.
} 
This measure can be considered as a comprehensive one to pinpoint whether a country has a RCA rather than to decide the fundamental sources of comparative advantage. The index estimates normalized export shares, considering the same industry exports in a group of observed nations. The measure accommodates comparative advantage for a particular industry for the time period and number of countries and therefore allows comparison. Some research articles evaluate global level RCA (e.g. Vollrath, 1991) and remaining others are at a sub-global/regional level or at bilateral trade between countries (e.g. Dimelis and Gatsios, 1995; Balassa, 1965).

The notion of RCA is well discussed in traditional trade theory. The RCA of a country is estimated by the comparative weight of a percentage of total exports of a particular industry in a country over the percentage of world exports in that industry and expressed as:

$\mathrm{RCA}=\frac{X_{i j} / X_{i g}}{X_{n j} / X_{n g}}=\frac{X_{i j} / X_{n j}}{X_{i g} / X_{n g}}$

where $\mathrm{X}$ signifies exports, $\mathrm{i}$ reflects a nation, $\mathrm{j}$ reflects a industry, $\mathrm{g}$ shows a set of industries and $\mathrm{n}$ reveals a group of nations. It calculates a nation's exports of industries in relations to its overall exports and to the matching exports of a group of nations. If RCA $>1$, a comparative advantage is shown; if $\mathrm{RAC}<1$, the nation is subject to a comparative disadvantage in that industry.

However, Greenaway and Milner (1993) argue that Balassa's RCA is biased due to the exclusion of imports. Based on this argument, another version of RCA can be derived by incorporating imports:

$\mathrm{RCA}=\frac{X_{i j} / X_{i g}}{M_{i j} / M_{i g}}=\frac{X_{i j} / M_{i j}}{X_{i g} / M_{i g}}$

where $\mathrm{X}$ and $\mathrm{M}$ represent exports and imports respectively. i represents a country, $\mathrm{j}$ represents a commodity and g represents a group of commodities (or industries). This RCA index can be measured either in global or bilateral levels.

Following the contributions of Balassa (1965) and Greenaway and Milner (1993), we will calculate the RCA index of PRC over Thailand $\left(R C A_{c t}\right.$, Equation 3$)$ and Thailand over PRC $\left(R C A_{t c}\right.$, Equation 4):

$R C A_{c t}=\frac{X_{c j t} / X_{c t}}{M_{t j w} / M_{t w}}$ 
$R C A_{t c}=\frac{X_{t j c} / X_{t c}}{M_{c j w} / M_{c w}}$

where $X_{c j t}=$ total exports of $\mathrm{j}^{\text {th }}$ commodity by China to Thailand;

$X_{c t}=$ total exports by China to Thailand;

$M_{t j w}=$ total imports of $\mathrm{j}^{\text {th }}$ commodity of Thailand from world;

$M_{t w}=$ total imports of Thailand from world;

$X_{t j c}=$ total exports of $\mathrm{j}^{\text {th }}$ commodity by Thailand to China;

$X_{t c}=$ total exports by Thailand to China;

$M_{c j w}=$ total imports of $\mathrm{j}^{\text {th }}$ commodity of China from world;

$M_{c w}=$ total imports of China from world.

Under the bilateral trade, if $R C A_{c t}>R C A_{t c}$ then China has advantage in that commodity in the market of Thailand; and if $R C A_{c t}<R C A_{t c}$ then China has disadvantage in that commodity in the market of Thailand.

In order to calculate the RCA of PRC with reference to Thailand, we use annual 2-digital SITC Revision 3 data covering PRC's exports and imports to Thailand and total imports from world for the period 2000-2013 from the UN Comtrade database.

\section{Results}

The aim is to explore the micro level comparative advantages using RCA indices on exports at HS-2 digit level between PRC and Thailand from the perspective of CAFTA in order to show that there is a catching up/diverging process between the two countries with the convergence towards a more competitive structure of RCA in exports. The analysis has been done splitting the sample into 2000-09 and 2010-13 reflecting both the 'investment' agreement in 2009 and subsequent increased in bilateral trade and investment. Presented is RCA of PRC with respect to Thailand. This is mainly due to show the shifting pattern of comparative advantage of PRC as PRC is the determining force as a big country. 
Table 1: RCA of PRC with respect to Thailand (product group, 2000-09 and 2010-13)

\begin{tabular}{|c|c|c|c|c|c|}
\hline & & \multicolumn{2}{|c|}{ Mean } & \multicolumn{2}{|c|}{ Coefficient of variation (per cent) } \\
\hline & & $2000-2009$ & 2010-2013 & $2000-2009$ & 2010-2013 \\
\hline 00 & Live animals & -0.75 & -0.18 & -166 & -32 \\
\hline 01 & Meat and meat preparations & 0.18 & 0.02 & 208 & 51 \\
\hline 02 & Dairy products and bird's eggs & 0.11 & -0.01 & 181 & -75 \\
\hline 03 & Fish crustaceans, molluscs & -1.06 & -0.29 & -147 & -104 \\
\hline 04 & Cereals and cereal preparations & -8.95 & -3.45 & -36 & -59 \\
\hline 05 & Vegetables and fruit & -8.89 & -8.55 & -28 & -31 \\
\hline 06 & Sugars, sugar preparations and honey & -4.61 & -1.20 & -78 & -391 \\
\hline 07 & Coffee, tea, cocoa, spices & 0.10 & 0.68 & 777 & 17 \\
\hline 08 & Feeding stuff for animals & 0.14 & -0.68 & 536 & -41 \\
\hline 09 & Miscellaneous edible products & 0.12 & -0.27 & 243 & -139 \\
\hline 11 & Beverages & 0.18 & 0.01 & 48 & 1105 \\
\hline 12 & Tobacco and tobacco manufactures & 0.64 & 0.41 & 61 & 35 \\
\hline 22 & Oil-seeds and oleaginous fruits & 0.11 & 0.26 & 73 & 34 \\
\hline 23 & Crude rubber & -11.98 & -14.13 & -14 & -18 \\
\hline 24 & Cork and wood & -1.54 & -2.75 & -23 & -17 \\
\hline 25 & Pulp and waste paper & -0.33 & 0.02 & -63 & 347 \\
\hline 26 & Textile fibers and their wastes & -0.25 & 0.08 & -169 & 134 \\
\hline 27 & Crude fertilizers and crude minerals & 1.96 & 1.59 & 31 & 6 \\
\hline 28 & Metallifeous ores and metal scrap & -0.03 & 0.09 & -202 & 41 \\
\hline 29 & Crude animal and vegetable materials & 2.05 & 2.18 & 30 & 12 \\
\hline 33 & Petroleum, petroleum products & -0.60 & -0.44 & -26 & -40 \\
\hline 34 & Gas, natural and manufactured & n.a. & -0.16 & n.a. & -67 \\
\hline 41 & Animal oils and fats & n.a. & n.a. & n.a. & n.a. \\
\hline 42 & Fixed vegetable fats and oils & 0.46 & 0.16 & 47 & 79 \\
\hline 43 & Animal or vegetable fats and oil, waxes & 0.09 & 0.52 & 405 & 23 \\
\hline 51 & Organic chemicals & -0.04 & -0.68 & -1057 & -63 \\
\hline 52 & Inorganic chemicals & 3.84 & 2.84 & 25 & 6 \\
\hline 53 & Dyeing, tanning and coloring materials & 0.91 & 0.44 & 13 & 35 \\
\hline 54 & Medicinal and pharmaceutical products & 0.65 & 0.74 & 21 & 12 \\
\hline 55 & Essential oils, perfume materials, cosmetic & -0.19 & -0.67 & -107 & -7 \\
\hline 56 & Fertilizers & 1.00 & 0.82 & 38 & 33 \\
\hline 57 & Plastics in primary forms & -1.98 & -2.02 & -24 & -17 \\
\hline 58 & Plastics in non-primary forms & 0.22 & 0.72 & 135 & 29 \\
\hline 59 & Chemical materials and products & 0.71 & -0.11 & 35 & -227 \\
\hline 61 & Leather and manufactures & -0.47 & -1.50 & -164 & -13 \\
\hline 62 & Rubber manufactures & -3.83 & -10.32 & -43 & -16 \\
\hline 63 & Cork and wood manufactures & -0.76 & 2.29 & -129 & 38 \\
\hline 64 & Paper, paperboard and articles thereof & -0.32 & 0.70 & -158 & 11 \\
\hline 65 & Textile yarn, fabrics, made-up articles & 3.18 & 3.44 & 11 & 2 \\
\hline 66 & Non-metallic mineral manufactures & -0.29 & 0.28 & -117 & 187 \\
\hline 67 & Iron and steel & 0.86 & 1.08 & 72 & 16 \\
\hline 68 & Non-ferrous metal & 0.92 & 0.69 & 39 & 15 \\
\hline 69 & Manufactures of metals & 0.44 & 0.55 & 22 & 16 \\
\hline 71 & Power-generating machinery and equipment & 0.33 & 0.29 & 91 & 88 \\
\hline 72 & Machinery specialized for particular industries & 0.93 & 1.29 & 27 & 12 \\
\hline 73 & Metalworking machinery & 0.31 & 0.49 & 54 & 18 \\
\hline 74 & General industrial machinery and equipment & 0.68 & 1.04 & 69 & 12 \\
\hline 75 & Office machinery and computers & -2.28 & -4.40 & -90 & -13 \\
\hline 76 & Telecommunication, sound, TV, video & 2.16 & 1.07 & 27 & 26 \\
\hline 77 & Electrical machinery, apparatus and appliances & -0.32 & -0.01 & -21 & -1620 \\
\hline 78 & Road vehicles & 0.43 & 0.64 & 43 & 21 \\
\hline
\end{tabular}




\begin{tabular}{|l|l|c|c|c|c|}
\hline 79 & Other transport equipment & 0.46 & 0.30 & 147 & 72 \\
\hline 81 & Prefabricated buildings, sanitary, heating, lighting & 5.10 & 4.46 & 22 & 50 \\
\hline 82 & Furniture and parts thereof; bedding, mattresses, & 2.79 & 9.19 & 105 & 29 \\
\hline 83 & Travel goods, handbags & 2.50 & 3.91 & 19 & 13 \\
\hline 84 & Articles of apparel and clothing accessories & 3.59 & 3.88 & 35 & 14 \\
\hline 85 & Footwear & 3.70 & 6.92 & 30 & 23 \\
\hline 87 & Professional, scientific and controlling instruments & 1.35 & 2.52 & 61 & 20 \\
\hline 88 & Photographic apparatus, equipment and supplies & 0.22 & 0.27 & 226 & 21 \\
\hline 89 & Miscellaneous manufactured articles & 0.72 & 0.76 & 29 & 61 \\
\hline
\end{tabular}

Source: Authors' estimated using SITC Rev. 3 data.

Note: Revealed comparative advantages are shown if index is greater than 1 .

Summary statistics (mean and coefficient of variation) are displayed in Table 1 (see appendix for annual detail). The industries for which China holds advantage reveals approximately the similar between the periods 2000-09 and 2010-13. In 2000-09 China had advantage in 37 industries and in 2010-13 in 39 industries. While 33 out of the 37 industries preserve their comparative advantage in 2010-13, 4 industries drop their advantage: dairy products and birds' eggs (02), feeding stuff for animals (07), miscellaneous edible products (09) and chemical materials and products (59). Six new industries have gained comparative advantage in 2010-13: pulp and waste paper (25), textile fibers and their wastes (26), metallifeous ores and metal scrap (28), cork and wood manufactures (63), paper, paperboard and articles thereof (64) and non-metallic mineral manufactures (66). Four industries each, gained or lost more than 10 ranks during this time as shown in Table 2.

\section{Table 2: Inter-temporal shift of PRC's RCA in Thai Market}

Industries for which PRC holds advantage: 37 in 2000-09, 39 in 2010-13

Industries that have retained advantage: 33

Industries that have gained advantage: 6 (SITC Codes: 25, 26, 28, 63, 64 and 66)

Industries that cannot hold advantage: 4 (SITC Codes: 02, 07, 09 and 59)

Industries that have gained/lost more than 10 ranks

Industries that have gained: 4 (SITC Codes: 43, 63, 64 and 66)

Industries that have lost: 4 (SITC Codes: 09, 42, 53 and 59)

Note: SITC Codes details are as appeared in Table 1. 
Table 3: PRC's Top Ten industries with a Comparative Advantage in Thai Market

\begin{tabular}{|c|l|l|}
\hline Rank & \multicolumn{1}{|c|}{$\mathbf{1 0 0 0 - 2 0 0 9}$} & \multicolumn{1}{|c|}{$\mathbf{1 0 1 0 - 2 0 1 3}$} \\
\hline 1 & $\begin{array}{l}\text { Prefabricated buildings, sanitary, heating, lighting } \\
(81)\end{array}$ & $\begin{array}{l}\text { Furniture and parts thereof; bedding, mattresses } \\
(82)\end{array}$ \\
\hline 2 & Inorganic chemicals (52) & Footwear (85) \\
\hline 3 & $\begin{array}{l}\text { Footwear } \\
(85)\end{array}$ & $\begin{array}{l}\text { Prefabricated buildings, sanitary, heating, lighting } \\
(81)\end{array}$ \\
\hline 4 & Articles of apparel and clothing accessories (84) & Travel goods, handbags (83) \\
\hline 5 & Textile yarn, fabrics, made-up articles (65) & Articles of apparel and clothing accessories (84) \\
\hline 6 & Furniture and parts thereof; bedding, mattresses (82) & Textile yarn, fabrics, made-up articles (65) \\
\hline 7 & Travel goods, handbags (83) & Inorganic chemicals (52) \\
\hline 8 & $\begin{array}{l}\text { Telecommunication, sound, TV, video } \\
\text { (76) }\end{array}$ & $\begin{array}{l}\text { Professional, scientific and controlling instruments } \\
\text { (87) }\end{array}$ \\
\hline 9 & Crude animal and vegetable materials (29) & Cork and wood manufactures (63) \\
\hline 10 & Crude fertilizers and crude minerals (27) & Crude animal and vegetable materials (29) \\
\hline
\end{tabular}

Note: SICT Codes in parentheses.

Of the 10 greatest competitive sectors for PRC in 2000-09, 8 hold their advantage in 20102013 (Table 3). While industries like telecommunication, sound, TV, video (SITC-76) and crude fertilizers and crude minerals (SITC-27) fail to keep the top ten set, industries like professional, scientific and controlling instruments (SITC-87) and cork and wood manufactures (SITC-63) join as China's best competitive sectors in 2010-13. Industries that revealed a loss of 10 or greater in their rank are chemical materials and products (from rank 19 to 43), dyeing, tanning and coloring materials (from rank 16 to 28), fixed vegetable fats and oils (from rank 23 to 35) and miscellaneous edible products (from rank 34 to 45). There are four industries which have shown an increase in their rank by 10 or more; Animal or vegetable fats and oils moves from 38 to 26 , cork and wood manufactures from 50 to 10 , Paper, paperboard and articles thereof from 46 to 21, and Non-metallic mineral manufactures from 44 to 32 (Table 2).

\section{Stability of RCA}

Table 1 shows the mean and the coefficients of variation. The coefficients of variation appeared in table 1 advocate that the RCA are reasonably steady and stable over the period 2000-2009 and 2010-2013 respectively. To examine this further, the relative importance of certain product group can be used as a simple indicator of stability (Hoekman and Djankov, 1997; Fertö and Hubbard, 2003; Utkulu and Seymen, 2004). The set product group can indicate a RCA at time period t while a revealed comparative disadvantage (RCD) at time period $\mathrm{t}+1$, or vice versa. 
The set of products in which PRC ensures RCA in 2000 but turned to RCD in 2009 account for $5.3 \%$ of the overall exports value to Thailand in 2000 and $4.5 \%$ in 2009 . A movement in the opposite ways occurred as follows, i.e. an RCD in 2000 but an RCA in 2009 account for $1.7 \%$ in 2000 and $3.4 \%$ in 2009 (Table 4). These results tend to give the assessment that the structure of PRC's RCA in Thailand market has not had substantial change during the period 2000-2009.

However, the set of product reveal slightly less stable pattern during the period 2010-2013. Even in those cases, China ensures an RCA in 2010 but an RCD in 2013 constitute $3.3 \%$ of the overall exports in 2010 and $2.1 \%$ in 2013 . The set of products for which there is a switch in opposite ways - an RCD in 2010 but an RCA in 2013-are more noticeable but only constitute $10.6 \%$ in 2010 and $11.4 \%$ in 2013 (Table 4). This would tend to support our argument that that the structure of PRC's RCA in Thailand market has not changed radically from 2010-2013.

For the whole period 2000-2013, the test still supports that the structure of China's reveal comparative advantage in Thailand market does not change remarkably, although the product groups are slightly more prevalent.

Table 4: Stability of RCA

\begin{tabular}{|l|c|c|c|c|}
\hline & \multicolumn{4}{|c|}{ Percentage share of product groups where: } \\
\hline \multirow{2}{*}{$2000-2009$} & $\mathrm{RCA}_{2000}$ & $\mathrm{RCD}_{2009}$ & $\mathrm{RCD}_{2000}$ & $\mathrm{RCA}_{2009}$ \\
\cline { 2 - 5 } & 5.3 & 4.5 & 1.7 & 3.4 \\
\hline \multirow{2}{*}{$2010-2013$} & $\mathrm{RCA}_{2010}$ & $\mathrm{RCD}_{2013}$ & $\mathrm{RCD}_{2010}$ & $\mathrm{RCA}_{2013}$ \\
\cline { 2 - 5 } & 3.3 & 2.1 & 10.6 & 11.4 \\
\hline \multirow{2}{*}{$2000-2013$} & $\mathrm{RCA}_{2000}$ & $\mathrm{RCD}_{2013}$ & $\mathrm{RCD}_{2000}$ & $\mathrm{RCA}_{2013}$ \\
\cline { 2 - 5 } & 3.5 & 2.8 & 14.8 & 13.6 \\
\hline
\end{tabular}

Source: Authors used SITC Rev. 3 data for calculations.

\section{Conclusions}

Both PRC and Thailand experienced increased trade and investment after signing CAFTA. This paper intends to fill the research gap by finding the competitiveness and stability of PRC's exports to Thailand and vice-versa. The findings of the competitiveness of PRC in relations to Thailand have been shown, based on the RCA, and computed for the period 2000 
to 2013 splitting the sample into 2000 - 09 and 2010 - 13 reflecting both the 'investment' agreement in 2009 and subsequent increased in bilateral trade and investment in the later period.

Our results show that China had an advantage in 39 industries in 2010-13. While 33 out of the 37 industries preserve their comparative advantage in 2010-13, 4 industries drop their advantage: dairy products and birds' eggs (02), feeding stuff for animals (07), miscellaneous edible products (09) and chemical materials and products (59). Six new industries have gained comparative advantage in 2010-13: pulp and waste paper (25), textile fibers and their wastes (26), metallifeous ores and metal scrap (28), cork and wood manufactures (63), paper, paperboard and articles thereof (64) and non-metallic mineral manufactures (66). This can be considered as shifting comparative advantage to Thailand. The structure of PRC's RCA in Thailand market has not changed remarkably during the whole period $2000-13$. Our findings of stability test confirm that results obtained are reasonably stable.

CAFTA is still in its infancy and can be considered as 'unfinished agenda'. PRC's currency policy focuses more on its own economic stability and this need to be more flexible to enhance more trade integration. Our results on positive trade performances in the light of comparative advantages are an encouraging sign for further integration. PRC as a rising power will maintain stable, harmonious relations with its neighbouring countries including Thailand and one would expect that PRC will commit deeper integration.

The RCA export performance indices are useful measure for policy makers if this is estimated over time to find the shift in comparative advantages. Our RCA export performance indices are purely calculated from observed trade data and are not accommodated potential effects of remaining government interventions, and price distortions due to that. Factors like transport, storage, distribution, communication and quality are also not taken into account in this calculation. The above limitations will be taken into account in future studies. 


\section{Reference}

Balassa, B (1965), Trade liberalisation and 'revealed' comparative advantage, the Manchester School, 33, 99-123.

Bank of Thailand (2014), Macro Economic Indicators, Bank of Thailand, Bank of Thailand,, Bangkok

Dimelis, S. and Gatsios, K. (1995), Trade with Central and Eastern Europe: the case of Greece, in R. Faini and R. Portes (eds.) EU Trade with Eastern Europe: Adjustment and Opportunities, London: CEPR.

Fertö, I. and Hubbard, L.J. (2003), Revealed comparative advantage and competitiveness in Hungarian Agri-food sectors, The Wolrd Economy, 26 (2), 247-259.

Greenaway, D. and Milner, C. (1993), Trade and industrial policy in developing countries: a manual of policy analysis, The Macmillan Press, esp. Part 4 Evaluating Comparative Advantage, 181-208.

Hoekman, B. and Djankov, s. (1997), Determinants of the export structure of countries in central and eastern Europe, World Bank Economic Review, 11, 471-487.

IMF (2014), Data and statistics, http://www.imf.org/external/data.htm, USA.

Laurenceson, J. (2003), Economic integration between China and the ASEAN-5, ASEAN Economic Bulletin, 20 (2), 103 - 111.

Ong, H-B. and Habibullah, M.S. (2012) Is China compatible with ASEAN - 5? A gradual cointegration analysis, Journal of Economic Studies, 39(3), 356 - 367.

Shen, H.F. (2013), The economic relations between China and Thailand under the context of CAFTA: an assessment, Chinese Studies 2 (1), $52-60$.

Thailand China Economic Information - The Long-stream friendship, http://www.thailandchina.com/getdoc/3aab868f-0b9e-4b1d-bcf1-e93bb80ec7b8/The-Long-stream.aspx?lang=en-GB, accessed on 16 September 2014.

Utkulu, U. and Seymen, D. (2004), revealed comparative advantage and competitiveness: evidence for Turkey vis-à-vis the EU/15, Presented at the European Trade Study Group $6^{\text {th }}$ Annual Conference, ETSG 2004, Nottingham. 
UN Comtrade Database (2014), http://comtrade.un.org/data/ accessed on 24 June 2014.

Vollrath, T. L. (1991), A theoretical evaluation of alternative trade intensity measures of revealed comparative advantage, Weltwirtschaftliches Archiv, 130, 265-79. 
Appendix Table: Revealed Comparative Advantages of China with Respect to Thailand, by Product Group, 2000-2013

\begin{tabular}{|c|c|c|c|c|c|c|c|c|c|c|c|c|c|c|c|}
\hline Code & Sector & 2000 & 2001 & 2002 & 2003 & 2004 & 2005 & 2006 & 2007 & 2008 & 2009 & 2010 & 2011 & 2012 & 2013 \\
\hline 00 & Live animals & -7.26 & -0.09 & -0.18 & -3.86 & -0.13 & -0.41 & -1.42 & -0.28 & -0.17 & -0.17 & -0.19 & -0.12 & -0.15 & -0.26 \\
\hline 01 & Meat and meat preparations & 11.49 & -0.58 & -0.10 & 0.29 & 0.15 & 0.61 & 0.75 & 0.20 & 0.25 & 0.09 & 0.01 & 0.02 & 0.03 & 0.04 \\
\hline 02 & Dairy products and bird's eggs & 0.04 & 0.00 & 0.00 & 0.02 & 0.01 & 0.05 & 0.02 & 0.59 & 0.27 & 0.02 & 0.00 & -0.01 & -0.01 & -0.02 \\
\hline 03 & Fish crustaceans, molluscs & -1.31 & -0.73 & -0.11 & -0.32 & -0.53 & -0.65 & -0.60 & -5.18 & -0.82 & -0.62 & -0.74 & -0.12 & -0.19 & -0.11 \\
\hline 04 & Cereals and cereal preparations & -6.05 & -8.47 & -7.63 & -8.42 & -4.75 & -5.66 & -13.28 & -14.25 & -10.30 & -7.75 & -5.55 & -4.81 & -1.38 & -2.05 \\
\hline 05 & Vegetables and fruit & -3.29 & -10.52 & -9.20 & -5.89 & -12.30 & -11.18 & -10.23 & -8.63 & -5.00 & -7.03 & -6.99 & -5.80 & -9.84 & -11.56 \\
\hline 06 & Sugars, sugar preparations and honey & -2.19 & -11.96 & -5.29 & -5.60 & -7.44 & -3.13 & -3.52 & -3.60 & 0.24 & -1.21 & 2.02 & -1.01 & -7.93 & 2.10 \\
\hline 07 & Coffee, tea, cocoa, spices & 0.41 & -0.26 & -0.71 & -0.96 & -0.84 & 0.38 & 0.76 & 0.75 & 0.80 & 1.01 & 0.63 & 0.86 & 0.62 & 0.63 \\
\hline 08 & Feeding stuff for animals & 1.16 & 1.04 & 1.06 & 0.52 & 0.45 & -0.01 & -0.41 & -1.36 & 0.05 & -0.08 & -1.07 & -0.47 & -0.49 & -0.69 \\
\hline 09 & Miscellaneous edible products & 0.55 & 0.28 & 0.16 & 0.51 & 0.45 & 0.15 & -0.04 & -0.12 & -0.40 & 0.06 & -0.08 & 0.01 & -0.19 & -0.82 \\
\hline 11 & Beverages & 0.16 & 0.29 & 0.35 & 0.13 & 0.18 & 0.15 & 0.17 & 0.12 & 0.14 & 0.09 & 0.11 & 0.08 & 0.09 & -0.22 \\
\hline 12 & Tobacco and tobacco manufactures & -0.09 & 0.35 & 0.81 & 1.31 & 0.72 & 0.98 & 0.20 & 0.30 & 0.42 & n.a. & 0.51 & n.a. & n.a. & 0.31 \\
\hline 22 & Oil-seeds and oleaginous fruits & 0.06 & 0.03 & 0.03 & 0.06 & 0.05 & 0.08 & 0.16 & 0.15 & 0.15 & 0.28 & 0.39 & 0.19 & 0.22 & 0.26 \\
\hline 23 & Crude rubber & -15.50 & -13.66 & -14.14 & -13.95 & -12.83 & -10.40 & -10.14 & -10.24 & -12.12 & -10.29 & -11.01 & -13.83 & -14.40 & -17.29 \\
\hline 24 & Cork and wood & -0.96 & -1.04 & -1.72 & -1.65 & -2.06 & -1.68 & -1.34 & -1.22 & -1.25 & -1.94 & -2.34 & -2.33 & -3.18 & -3.14 \\
\hline 25 & Pulp and waste paper & -1.11 & -0.79 & -0.41 & -0.44 & -0.21 & -0.17 & -0.33 & -0.38 & -0.16 & -0.11 & -0.01 & 0.05 & 0.09 & -0.06 \\
\hline 26 & Textile fibres and their wastes & 0.77 & -0.67 & -0.46 & 0.48 & -0.69 & -0.68 & -0.29 & -0.09 & 0.10 & 0.09 & 0.04 & -0.03 & 0.22 & 0.09 \\
\hline 27 & Crude fertilizers and crude minerals & 2.77 & 3.34 & 2.16 & 1.97 & 1.81 & 1.76 & 1.85 & 2.00 & 1.75 & 1.03 & 1.52 & 1.55 & 1.53 & 1.74 \\
\hline
\end{tabular}




\begin{tabular}{|c|c|c|c|c|c|c|c|c|c|c|c|c|c|c|c|}
\hline 28 & Metallifeous ores and metal scrap & 0.39 & 0.04 & 0.04 & 0.01 & -0.03 & -0.03 & -0.06 & -0.11 & -0.12 & 0.00 & 0.07 & 0.10 & 0.05 & 0.13 \\
\hline 29 & Crude animal and vegetable materials & 1.55 & 2.42 & 2.26 & 1.48 & 3.01 & 2.97 & 1.51 & 1.53 & 1.49 & 2.32 & 1.89 & 2.06 & 2.45 & 2.33 \\
\hline 33 & Petroleum, petroleum products & 0.10 & -0.42 & -0.69 & -0.86 & -0.51 & -0.47 & -0.49 & -0.72 & -0.73 & -0.48 & -0.35 & -0.25 & -0.50 & -0.66 \\
\hline 34 & Gas, natural and manufactured & n.a. & n.a. & n.a. & n.a. & n.a. & n.a. & n.a. & n.a. & n.a. & n.a. & n.a. & -0.04 & -0.23 & -0.20 \\
\hline 41 & Animal oils and fats & 0.00 & 0.06 & 0.00 & 0.01 & -0.04 & -0.07 & 0.00 & -0.02 & 0.03 & 0.03 & n.a. & n.a. & n.a. & n.a. \\
\hline 42 & Fixed vegetable fats and oils & 1.27 & 0.87 & 0.39 & 0.59 & 0.33 & 0.52 & 0.30 & 0.65 & 0.15 & 0.35 & 0.35 & 0.13 & 0.10 & 0.06 \\
\hline 43 & Animal or vegetable fats and oil, waxes & 0.00 & 0.00 & -0.37 & -0.08 & -0.10 & -0.19 & -0.03 & 0.44 & 0.64 & 0.39 & 0.36 & 0.53 & 0.65 & 0.53 \\
\hline 51 & Organic chemicals & 0.43 & 0.64 & 0.11 & -0.04 & -0.02 & -0.02 & -0.90 & -0.53 & 0.27 & 0.12 & -0.17 & -0.51 & -0.90 & -1.14 \\
\hline 52 & Inorganic chemicals & 5.33 & 5.04 & 5.15 & 4.65 & 4.18 & 3.59 & 3.16 & 2.78 & 2.69 & 3.31 & 3.08 & 2.77 & 2.79 & 2.72 \\
\hline 53 & Dyeing, tanning and colouring materials & 0.88 & 1.06 & 0.99 & 0.95 & 0.92 & 0.95 & 0.92 & 0.98 & 0.81 & 0.64 & 0.54 & 0.59 & 0.27 & 0.34 \\
\hline 54 & Medicinal and pharmaceutical products & 1.05 & 0.91 & 0.79 & 0.57 & 0.53 & 0.50 & 0.59 & 0.56 & 0.71 & 0.73 & 0.76 & 0.85 & 0.67 & 0.67 \\
\hline 55 & Essential oils, perfume materials, cosmetic & -0.02 & 0.10 & 0.07 & -0.24 & -0.23 & -0.13 & -0.11 & -0.22 & -0.41 & -0.53 & -0.61 & -0.68 & -0.71 & -0.68 \\
\hline 56 & Fertilizers & 0.00 & 0.00 & 0.00 & 0.00 & 1.21 & 0.52 & 0.67 & 1.57 & 1.14 & 0.90 & 1.06 & 1.02 & 0.69 & 0.50 \\
\hline 57 & Plastics in primary forms & -2.60 & -2.55 & -2.62 & -2.22 & -2.23 & -2.13 & -1.88 & -1.40 & -1.52 & -1.31 & -1.62 & -1.94 & -2.08 & -2.43 \\
\hline 58 & Plastics in non-primary forms & -0.40 & 0.05 & -0.17 & -0.16 & -0.03 & 0.37 & 0.51 & 0.56 & 0.49 & 0.36 & 0.46 & 0.65 & 0.85 & 0.93 \\
\hline 59 & Chemical materials and products & 0.49 & 0.95 & 0.86 & 0.94 & 0.64 & 0.81 & 0.77 & 0.63 & 0.59 & 0.16 & -0.14 & 0.07 & 0.08 & -0.47 \\
\hline 61 & Leather and manufactures & 0.19 & 0.81 & 0.06 & -0.30 & -0.07 & -0.26 & -0.45 & -0.88 & -1.64 & -1.47 & -1.56 & -1.30 & -1.40 & -1.73 \\
\hline 62 & Rubber manufactures & -2.20 & -1.68 & -2.19 & -3.76 & -3.94 & -2.92 & -4.88 & -4.28 & -5.58 & -6.89 & -8.67 & -9.29 & -10.89 & -12.42 \\
\hline 63 & Cork and wood manufactures & -0.42 & -1.78 & -2.19 & -1.91 & -0.95 & -1.13 & 0.34 & 0.57 & 0.04 & -0.17 & 1.24 & 3.33 & 2.14 & 2.46 \\
\hline 64 & Paper, paperboard and articles thereof & -1.04 & -0.85 & -0.81 & -0.52 & -0.57 & -0.35 & 0.22 & 0.27 & 0.02 & 0.37 & 0.61 & 0.69 & 0.72 & 0.80 \\
\hline
\end{tabular}




\begin{tabular}{|c|c|c|c|c|c|c|c|c|c|c|c|c|c|c|c|}
\hline 65 & Textile yarn, fabrics, made-up articles & 3.21 & 3.26 & 2.69 & 3.18 & 2.67 & 3.03 & 3.14 & 3.25 & 3.54 & 3.84 & 3.51 & 3.51 & 3.36 & 3.40 \\
\hline 66 & Non-metallic mineral manufactures & -0.39 & -0.46 & -0.89 & -0.72 & -0.43 & -0.24 & 0.03 & 0.02 & 0.03 & 0.11 & -0.11 & -0.14 & 0.39 & 0.98 \\
\hline 67 & Iron and steel & 0.73 & 0.19 & 0.03 & 0.01 & 1.43 & 1.44 & 1.67 & 1.05 & 1.30 & 0.71 & 0.86 & 1.21 & 1.23 & 1.03 \\
\hline 68 & Non-ferrous metal & 0.41 & 0.55 & 0.57 & 1.20 & 1.49 & 1.30 & 1.01 & 0.96 & 1.05 & 0.68 & 0.67 & 0.55 & 0.74 & 0.79 \\
\hline 69 & Manufactures of metals & 0.22 & 0.45 & 0.48 & 0.43 & 0.33 & 0.48 & 0.47 & 0.49 & 0.55 & 0.45 & 0.43 & 0.64 & 0.57 & 0.57 \\
\hline 71 & Power-generating machinery and equipment & 0.31 & 0.08 & -0.21 & 0.20 & 0.45 & 0.11 & 0.39 & 0.47 & 0.76 & 0.74 & 0.38 & 0.58 & 0.25 & -0.04 \\
\hline 72 & Machinery specialized for particular industries & 0.62 & 0.77 & 0.63 & 0.81 & 0.87 & 0.90 & 1.03 & 1.15 & 1.13 & 1.40 & 1.19 & 1.18 & 1.27 & 1.52 \\
\hline 73 & Metalworking machinery & 0.18 & 0.16 & 0.21 & 0.28 & 0.15 & 0.24 & 0.30 & 0.45 & 0.55 & 0.63 & 0.53 & 0.47 & 0.38 & 0.58 \\
\hline 74 & General industrial machinery and equipment & -0.21 & 0.16 & 0.49 & 0.50 & 0.56 & 0.76 & 1.06 & 1.19 & 1.19 & 1.05 & 1.08 & 1.19 & 0.91 & 0.98 \\
\hline 75 & $\begin{array}{l}\text { Office machinery and automatic data-processing } \\
\text { machines }\end{array}$ & -0.66 & -0.28 & -0.14 & -0.73 & -1.64 & -1.95 & -2.35 & -4.02 & -5.73 & -5.32 & -4.31 & -4.93 & -4.73 & -3.62 \\
\hline 76 & Telecommunication, sound, TV, video & 1.68 & 2.65 & 2.77 & 2.28 & 1.90 & 2.26 & 2.69 & 2.56 & 1.98 & 0.87 & 0.66 & 1.14 & 1.17 & 1.32 \\
\hline 77 & Electrical machinery, apparatus and appliances & -0.47 & -0.39 & -0.29 & -0.26 & -0.30 & -0.34 & -0.29 & -0.33 & -0.27 & -0.25 & -0.29 & -0.10 & 0.15 & 0.19 \\
\hline 78 & Road vehicles & 0.29 & 0.26 & 0.25 & 0.37 & 0.18 & 0.48 & 0.56 & 0.62 & 0.74 & 0.58 & 0.48 & 0.66 & 0.63 & 0.81 \\
\hline 79 & Other transport equipment & 2.08 & 0.43 & 1.13 & 0.01 & 0.02 & 0.04 & 0.03 & 0.10 & 0.20 & 0.54 & 0.60 & 0.14 & 0.31 & 0.15 \\
\hline 81 & Prefabricated buildings, sanitary, heating, lighting & 7.22 & 6.31 & 5.13 & 4.23 & 4.68 & 5.76 & 3.89 & 3.55 & 5.27 & 4.98 & 3.28 & 2.96 & 3.84 & 7.78 \\
\hline 82 & Furniture and parts thereof; bedding, mattresses, & 0.56 & 0.47 & 1.01 & 1.60 & 1.65 & 1.86 & 2.00 & 3.65 & 4.89 & 10.20 & 22.61 & 9.67 & 6.24 & 8.23 \\
\hline 83 & Travel goods, handbags & 2.48 & 2.24 & 2.37 & 3.11 & 2.53 & 2.07 & 2.10 & 1.97 & 3.39 & 2.76 & 3.17 & 4.29 & 4.08 & 4.11 \\
\hline 84 & Articles of apparel and clothing accessories & 5.55 & 3.69 & 3.99 & 4.23 & 2.01 & 2.18 & 2.12 & 3.59 & 5.24 & 3.32 & 3.66 & 3.61 & 3.56 & 4.69 \\
\hline 85 & Footwear & 4.31 & 4.84 & 4.87 & 4.40 & 2.54 & 1.90 & 2.56 & 3.26 & 3.56 & 4.74 & 6.78 & 5.84 & 5.83 & 9.24 \\
\hline
\end{tabular}




\begin{tabular}{|c|c|c|c|c|c|c|c|c|c|c|c|c|c|c|c|}
\hline 87 & professional, scientific and controlling instruments & 0.41 & 0.48 & 0.78 & 1.55 & 0.96 & 1.05 & 1.45 & 1.35 & 2.54 & 2.92 & 2.71 & 3.04 & 2.46 & 1.87 \\
\hline 88 & photographic apparatus, equipment and supplies & 0.88 & 1.14 & 0.47 & -0.02 & -0.34 & 0.02 & -0.12 & -0.26 & 0.00 & 0.43 & 0.23 & 0.25 & 0.25 & 0.36 \\
\hline 89 & Miscellaneous manufactured articles & 0.55 & 0.62 & 0.42 & 0.50 & 0.64 & 0.74 & 0.86 & 1.04 & 0.89 & 0.94 & 0.90 & 0.98 & 1.09 & 0.08 \\
\hline
\end{tabular}

Source: Authors' calculation based on SITC Rev. 3 data.

Note: Revealed comparative advantages are shown if index is greater than 1 . 